\title{
HUBUNGAN DUKUNGAN KELUARGA DAN STRATEGI PENANGANAN KECEMASAN PADA PERAWAT YANG MERAWAT PASIEN PENDERITA COVID-19
}

\author{
Aristina Halawa ${ }^{1}$ \\ ${ }^{1}$ STIKes William Booth Surabaya.Jl.Cimanuk No.20 Surabaya \\ Email : halawaaristina@yahoo.co.id
}

\begin{abstract}
ABSTRAK
Covid-19 mulai masuk ke Indonesia pada awal tahun 2020 dan menyebar ke seluruh daerah di Indonesia. Hal ini menimbulkan kecemasan bukan hanya pada masyarakat namun juga kepada perawat. Kecemasan ini dialami oleh perawat karena perawat merupakan garda terdepan dalam merawat pasien Covid-19. Perawat perlu melakukan strategi penanganan kecemasannya seperti menerapkan pola hidup sehat, menjaga pola makan dan menghindari perilaku yang beresiko agar dapat menjalankan tugasnya dengan baik. Dalam hal ini dukungan keluarga sangat dibutuhkan oleh perawat karena dukungan keluarga merupakan motivasi bagi perawat. Tujuan dari penelitian ini adalah untuk mengidentifikasi hubungan dukungan keluarga dan strategi penanganan kecemasan pada perawat yang merawat pasien penderita covid-19. Metode yang digunakan dalam penelitian ini adalah menggunakan metode crosssectional. Jumlah populasi pada penelitian ini sebanyak 35 dengan jumlah sampel 35 orang perawat yang bekerja merawat pasien penderita Covid-19. Pengambilan sampel dilakukan dengan cara Total Sampling. Instrument penelitian yang digunakan adalah kuesioner. Hasil penelitian menunjukkan sebanyak $15(42,8 \%)$ responden memiliki dukungan keluarga baik, $18(51,4 \%)$ responden memiliki dukungan keluarga cukup dan $2(5,8 \%)$ memiliki dukungan kurang. Strategi penanganan kecemasan perawat sebagian besar yaitu $23(65,7 \%)$ responden berada pada tingkat baik dan $12(34,3 \%)$ responden berada pada tingkat cukup. Analisa data menggunakan uji spearman dan diperoleh nilai signifikasi (p) sebesar 0,007 yang berarti ada hubungan antara dukungan keluarga dan strategi penanganan kecemasan pada perawat yang merawat pasien penderita covid-19. Dengan demikian diharapkan keluarga terus mempertahankan dan meningkatkan dukungannya kepada perawat dan perawat tetap mempertahankan strategi penanganan kecemasanya selama merawat pasien Covi-19 sehingga dapat menjalankan tugasnya dengan baik.
\end{abstract}

Kata Kunci :Family Support, Strategi Penanganan Kecemasan, Perawat, Covid-19

\begin{abstract}
Covid-19 began to enter Indonesia in early 2020 and spread to all regions in Indonesia. This causes anxiety not only in the community but also for nurses. This anxiety is experienced by nurses because nurses are at the forefront of treating Covid-19 patients. Nurses need to carry out anxiety management strategies such as implementing a healthy lifestyle, maintaining a healthy diet and avoiding risky behavior in order to carry out their duties properly. In this case, family support is needed by nurses because family support is a motivation for nurses. The purpose of this study was to identify the relationship between family support and anxiety management strategies for nurses who treat patients with COVID-19. The method used in this study is a cross-sectional method. The total population in this study was 35 with a sample of 35 nurses who worked to treat patients with Covid-19. Sampling is done by Total Sampling. The research instrument used was a questionnaire. The results showed as many as $15(42.8 \%)$ respondents had good family support, 18 (51.4\%) respondents had sufficient family
\end{abstract}


support and $2(5.8 \%)$ had less support. Most of the nurses' anxiety management strategies were $23(65.7 \%)$ respondents were at a good level and $12(34.3 \%)$ respondents were at a sufficient level. Analysis of the data using the Spearman test and obtained a significance value (p) of 0.007 which means there is a relationship between family support and anxiety management strategies for nurses who treat patients with COVID-19. Thus, it is hoped that families will continue to maintain and increase their support for nurses and nurses while maintaining their anxiety management strategies while treating Covid-19 patients so that they can carry out their duties properly.

Keywords: Anxiety, Anxiety Management Strategy, Nurse, Covid-19.

\section{PENDAHULUAN}

Covid-19 merupakan sebuah penyakit yang berasal dari Coronaviruses $(\mathrm{CoV})$. Virus ini pertama kali ditemukan di Wuhan, China pada penghujung tahun 2019 yang terjadi di dalam lingkungan Pasar Makanan Laut Huanan, China. Virus ini diperkirakan berasal dari kelelawar dan kemudian menyebar ke manusia melalui kontaminasi daging yang dijual dengan limbah hewan liar. Coronaviruses (CoV) merupakan bagian dari keluarga virus yang menyebabkan penyakit saluran pernafasan seperti Middle East Respiratory Syndrome (MERS-CoV) and Severe Acute Respiratory Syndrome (SARS-CoV). Gejala virus tersebut di antaranya batuk, demam, letih, sesak napas, dan tidak nafsu makan. Penyebaran dan penularan virus Covid-19 dapat melalui berbagai hal, salah satunya melalui droplet saat seseorang batuk, bersin, berbicara, hingga bernapas. Selain itu virus juga menular melalui udara, permukaan benda yang terkontaminasi dan melalui fecal-oral. Virus Covid-19 ini mulai masuk ke Indonesia sejak awal tahun 2020 dan menyebar ke seluruh daerah di Indonesia, dan pada tanggal 11 Maret 2020 ditetapkan sebagai pandemic Covid-19. Krisis kesehatan pandemi Covid-19 ini menyebabkan perubahan psikologis seperti ketakutan, kecemasan, depresi, atau ketidakamanan (Rina Tri Handayani, 2020). Salah satu gangguan mental yang terjadi pada pandemi Covid-19 ini ialah kecemasan. Kecemasan merupakan kondisi emosi dimana timbulnya rasa tidak nyaman pada diri seseorang, dan merupakan pengalaman yang samar- samar disertai dengan perasaan yang tidak berdaya serta tidak menentu yang disebabkan oleh suatu hal yang belum jelas (Annisa \& Ifdil, 2016). Kecemasan tidak hanya dirasakan oleh masyarakat saja, namun juga dialami seluruh tenaga kesehatan seperti dokter, perawat, bidan dan profesi kesehatan lainnya. Respon psikologis yang dialami oleh tenaga kesehatan terhadap pandemi penyakit menular ini menjadi meningkat karena disebabkan oleh perasaan cemas terhadap kesehatan sendiri dan penyebaran terhadap keluarga (Fadli, 2020).

Kecemasan yang dialami perawat antara lain takut tertular virus Covid-19 karena seringnya terpapar dengan pasien, penggunaan APD yang lengkap seperti pakaian hazmat dan masker N95 yang membuat pelayanan jauh lebih sulit dan melelahkan dibandingkan dengan kondisi normal, takut menularkan virus ke keluarga karena tenaga kesehatan sebagai carrier (pembawa virus), perasaan was-was ketika ingin keluar rumah, meningkatnya beban kerja dibanding biasanya serta mengkhawatirkan kesehatan diri sendiri dan keluarga. Menurut Fadli (2020) factor yang mempengaruhi kecemasan perawat pada masa pandemic ini yaitu ketersediaan alat pelindung diri, status keluarga kejujuran pasien, dan pengetahuan. Tanda dari cemas yang dirasakan oleh perawat yaitu selalu merasa was-was ketika ingin keluar rumah, jari tangan dingin, detak 
jantung cepat, kepala pusing, tidak nafsu makan, mengalami gangguan tidur (insomnia), dan dada terasa sesak. Untuk mencegah terjadinya dampak dari kecemasan ini maka perawat melakukan berbagai strategi penangan kecemasan agar tetap dapat menjalankan tugasnya sebagai perawat dan tetap sehat. Strategi Perawat dalam menangani kecemasan karena Covid-19 ini yaitu rajin mencuci tangan, menggunakan masker ketika berada dilingkungan rumah sakit dan luar rumah, makan makanan sehat dan bergizi, menjaga jarak minimal 1 meter dan menghindari kerumunan (Kemenkes, 2020). Namun hal ini tentu tidak mudah karena situasinya sangat menekan dan dapat mengancam kesehatan dari perawat itu sendiri. Individu yang berada dalam situasi yang tertekan dan berusaha untuk mengatasi situasi tersebut membutuhkan dukungan. Menurut Taylor (1999) bahwa seseorang yang medapat dukungan social yang tinggi akan lebih berhasil dalam menghadapi stress dibandingkan dengan yang tidak memperoleh dukungan social. Keluarga adalah salah satu dukungan social bagi Perawat. Perawat yang mengalami situasi yang menekan akan menyampaikan keluhan-keluhannya kepada keluarga dan keluarga akan memberikan solusi terhadap masalah yang dihadapi (Irwanto, 2002). Keluarga merupakan tempat yang paling nyaman untuk seseorang dalam menghadapi segala persoalan hidup, berbagi kebahagiaan dan tempat tumbuhnya harapan-harapan akan hidup yang lebih baik. Hal ini sesuai juga dengan peneitian Rina Tri Handayani (2020) yang menyatakan bahwa dukungan keluarga memiliki peran penting dalam hal mendukung staf layanan kesehatan dari semua latar belakang dalam menangani dampak psikologis di masa pandemi. Perawat membutuhkan dukungan dari keluarga Ketika mereka sendiri berusaha untuk menngatasi kecemasan yang sedang mereka alami dengan selalu membersihkan diri dan mandi setelah memasuki ruang perawatan, menggunakan APD lengkap dan sesuai standar, rajin mencuci tangan, menggunakan masker, makan makanan bergizi serta rutin mengkonsumsi suplement dan vitamin untuk meningkatkan daya tahan tubuh sehingga mereka tetap dalam keadaan sehat dan keluarga mereka juga sehat.

Menurut data WHO (2020) menunjukkan sebanyak 106 Negara terpapar virus corona, jumlah penderita di dunia sekitar 72,8 juta kasus yang terinfeksi Covid-19. Dari 72,8 juta kasus positif korona, 1,62 juta $(2,23 \%)$ pasien Covid-19 telah meninggal dunia dan 41,3 juta $(56,7 \%)$ pasien Covid-19 telah sembuh dari total kasus positif. Di Indonesia, data terakhir tentang jumlah kasus positif virus corona (Covid-19) masih menunjukkan peningkatan sejak bulan Oktober hingga Desember 2020 yaitu sebanyak 623.000 kasus positif corona, $18.956(3,04 \%)$ pasien Covid-19 telah meninggal dunia dan $511.000(82,02 \%)$ pasien Covid-19 telah sembuh. Di Jawa Timur kasus positif Covid-19 sekitar 70.634 kasus positif corona, 4.920 pasien $(6,96 \%)$ meninggal dunia dan 60.980 pasien $(86,3 \%)$ telah sembuh. Sedangkan Surabaya sendiri merupakan kota tertinggi kasus Covid-19 di Provinsi Jawa Timur, jumlah kasus positif corona pada bulan Oktober sebanyak 3.143 pasien, bulan November sebanyak 4.617 pasien dan bulan Desember sebanyak 7.199 pasien, jumlah peningkatan kasus Covid dari bulan Oktober hingga Desember meningkat hingga 100\%. Dari perbandingan data diatas dapat disimpulkan bahwa di Indonesia, khusunya di provinsi Jawa Timur dan Kota Surabaya kasus ini masih mengalami peningkatan dari jumlah kematian dan tingkat kesembuhan pasien. Selain itu petugas kesehatan yang mengalami kasus positif corona sekitar 6.680 tenaga kesehatan dan 2.979 (44,5\%) diantaranya adalah perawat. Dari data diatas jumlah perawat di Surabaya yang saat ini berjumlah 6.926 tenaga perawat dan $67 \%$ diantaranya atau sekitar 4.640 perawat merawat pasien dengan Covid-19. Hal ini tentu menimbulkan kecemasan dan stress 
yang luar biasa bagi perawat. Respon psikologis yang sering muncul pada perawat ialah perasaan cemas dan tegang sebanyak 70\% (Dinah, 2020). Selain cemas respon psikologis dapat berupa despresi, insomnia, dan tekanan psikologis akibat beban kerja yang meningkat. Jurnal lain hasil Penelitian Lai et al (2020) pada jurnal Pendidikan Keperawatan Indonesia mengatakan tenaga kesehatan beresiko mengalami gangguan psikologis dalam mengobati pasien Covid-19, hasil menunjukkan bahwa $50,4 \%$ responden memiliki gejala depresi dan $44,6 \%$ memiliki gejala kecemasan karena perasaan tertekan.

Factor yang mempengaruhi kecemasan pada perawat tentunya juga beragam seperti usia, status kesehatan, dukungan sosial dan dukungan keluarga, pekerjaan serta mekanisme koping yang dimiliki oleh setiap individu. (Untari, 2014). Menurut Brooks (2020) penyebab tenaga kesehatan mengalami kecemasan yakni tuntutan pekerjaan yang tinggi, termasuk waktu kerja yang lama jumlah pasien meningkat, semakin sulit mendapatkan dukungan sosial karena adanya stigma masyarakat terhadap petugas garis depan, alat perlindungan diri yang membatasi gerak, kurang informasi tentang paparan jangka Panjang pada orang-orang yang terinfeksi, dan rasa takut petugas garis depan akan menularkan Covid-19 pada teman dan keluarga karena bidang pekerjaannya. Ketika para tenaga kesehatan menganggap dirinya dalam situasi yang berbahaya tentunya akan menimbulkan kecemasan yang cukup tinggi. Dampak dari kecemasan ini tentu mengganggu kondisi fisik dan mental seperti simpson suasana hati, kognitif dan symptom motor yang menyabakan mudah marah, menggangu aktivitas sehari-hari, dan kecemasan yang terlalu berlebihan (Stuart and Sundeen, 2000). Dampak dari cemas tidak hanya menggangu kondisi fisik dan mental saja namun juga berdampak pada tingkat ekonomi, kebanyakan pekerja dirumahkan akibat dari virus Covid-19 sehingga mereka khawatir tidak dapat mencukupi kebutuhan ekonomi diri sendiri dan keluarga. Gangguan kecemasan tidak dapat disepelekan dan perlu penanganan yang tepat, terlebih jika gangguan kecemasan tersebut sudah menggangu aktivitas seharihari dan aktivitas sosial terlebih jika sudah muncul perasaan untuk bunuh diri dan menyakiti diri sendiri atau orang lain. (Ramsberger, Legree, Milles, 2003). Oleh karena itu penting sekali perawat mendapat dukungan dari keluarga dalam menangani kecemsan mereka. Berdasarkan penelitian Nuuferulla (2011) Dukungan sosial keluarga yang berupa dukungan emosional, dukungan penghargaan, dukungan, instrumental dan dukungan informatif berpengaruh negatif terhadap tingkat burnout yang terjadi pada perawat kesehatan di RSJ Prof. dr. Soerojo yang artinya semakin tinggi dukungan sosial keluarga maka semakin rendah tingkat burnout yang terjadi.

Berdasarkan masalah diatas solusi yang dapat dilakukan oleh perawat dalam upaya untuk mengurangi kecemasan menurut (Balasubramanian, Paleri, Bennett, Paleri, 2020) yaitu mengajarkan para tenaga kesehatan untuk menerapkan strategi koping, kita bisa memulai koping dengan beberapa langkah seperti menerapkan perilaku gaya hidup positif yang dapat meningkatkan kesejahteraan kesehatan mental, makan makanan sehat dan bergizi, melakukan olahraga yang teratur, menjaga istirahat yang cukup antar shift, serta rutin mengkonsumsi suplemen dan vitamin yang dapat meningkatkan daya tahan tubuh. Menghindari perilaku berisiko tinggi seperti pengeluaran yang berlebihan dan penggunaan media sosial yang berlebihan untuk melihat informasi yang berkaitan dengan Covid-19 yang juga dapat berdampak negatif pada kesehatan mental. Menjaga dan memenuhi kelengkapan APD tim perawatan covid-19 juga merupakan salah satu cara menurunkan gangguan psikologis dan kecemasan yang mereka 
alami. Selain itu menurut penelitian Rina Tri Handayani, dkk (2020) pada jurnal Ilmu Keperawatan Jiwa PPNI Jawa Tengah menyebutkan bahwa strategi yang dapat diterapkan dalam mengatasi kecemasan pada tenaga perawat dengan metode Battle Buddies yaitu menempatkan tenaga psikolog dengan cepat untuk memvalidasi stressor. Selain itu juga mengajarkan tenaga kesehatan untuk mempertahankan koping dan meningkatkan dukungan keluarga, sosial dan insitusi pelayanan dalam upaya untuk mengatasi tingkat kecemasan. Dukungan keluarga berupa dukungan emosional, dukungan penghargaan, dukungan instrumental dan dukungan informatif penting bagi perawat dalam melaksanakan strategi penanganan kecemasan mereka.

\section{METODE}

Penelitian ini menggunakan jenis penelitian kuantitatif dengan metode korelasional. Jumlah populasi pada penelitian ini adalah sebanyak 35 dengan jumlah sampel yang digunakan sebagai responden penelitian adalah sebanyak 35 responden perawat ruang Covid-19 RSUD Bhakti Dharma Husada. Pengambilan sampel dilakukan dengan cara Total Sampling. Variabel bebas (independen) pada penelitian ini adalah Dukungan Keluarga sedangkan variabel terikat (dependen) pada penelitian ini adalah strategi penanganan kecemasan Perawat. Instrumen penelitian yang digunakan adalah kuesioner. Hasil penelitian yang didapat di analisa dengan menggunakan uji Spearman.

\section{HASIL PENELITIAN}

\section{Data Umum}

Tabel 1 : Distribusi frekuensi karakteristik responden berdasarkan usia

\begin{tabular}{|l|c|c|}
\hline Usia (tahun) & Jumlah & Presentase (\%) \\
\hline $20-30$ tahun & 28 & $80 \%$ \\
\hline $31-40$ tahun & 6 & $17,2 \%$ \\
& & \\
\hline $41-50$ tahun & 1 & $2,8 \%$ \\
\hline$>50$ tahun & 0 & $0 \%$ \\
\hline TOTAL & $\mathbf{3 5}$ & $\mathbf{1 0 0} \%$ \\
\hline
\end{tabular}

Berdasarkan tabel 1 didapatkan data dari 35 responden sebagian besar berusia 20-30 tahun yaitu 28 orang (80\%).

Tabel 2 Distribusi frekuensi karakteristik responden berdasarkan lama bekerja

\begin{tabular}{|l|c|c|}
\hline Lama Bekerja & Jumlah & Presentase $(\%)$ \\
\hline$<5$ tahun & 22 & $62,8 \%$ \\
\hline $5-10$ tahun & 7 & $20 \%$ \\
\hline$>10$ tahun & 6 & $17,2 \%$ \\
\hline TOTAL & $\mathbf{3 5}$ & $\mathbf{1 0 0} \%$ \\
\hline
\end{tabular}

Berdasarkan tabel 2 didapatkan data dari 35 responden sebagian besar sudah bekerja selama $<5$ tahun yaitu 22 orang $(62,8 \%)$.

Tabel 3 Distribusi frekuensi karakteristik responden berdasarkan pendidikan

\begin{tabular}{|l|c|c|}
\hline \multicolumn{1}{|c|}{ Pendidikan } & Jumlah & Presentase (\%) \\
\hline D3 Keperawatan & 28 & $80 \%$ \\
\hline S1 Keperawatan & 7 & $20 \%$ \\
\hline TOTAL & $\mathbf{3 5}$ & $\mathbf{1 0 0} \%$ \\
\hline
\end{tabular}

Berdasarkan tabel 3 didapatkan data dari 35 responden sebagian besar dari pendidikan D3 Keperawatan yaitu 28 orang $(80 \%)$

Tabel 4 Distribusi frekuensi karakteristik responden berdasarkan status perkawinan

\begin{tabular}{|l|c|c|}
\hline Status Perkawinan & Jumlah & $\begin{array}{c}\text { Presentase } \\
(\%)\end{array}$ \\
\hline Menikah & 11 & $31,4 \%$ \\
\hline Belum Menikah & 24 & $68,6 \%$ \\
\hline Janda & 0 & $0 \%$ \\
\hline Duda & 0 & $0 \%$ \\
\hline TOTAL & $\mathbf{3 5}$ & $\mathbf{1 0 0} \%$ \\
\hline
\end{tabular}


Berdasarkan tabel 4 didapatkan data dari 35 responden sebagian besar belum menikah yaitu 24 orang $(68,6 \%)$

Tabel 5 Distribusi frekuensi karakteristik responden berdasarkan tinggal serumah bersama

\begin{tabular}{|l|c|c|}
\hline \multicolumn{1}{|c|}{$\begin{array}{c}\text { Tinggal Serumah } \\
\text { Bersama }\end{array}$} & Jumlah & $\begin{array}{c}\text { Presentase } \\
(\%)\end{array}$ \\
\hline Keluarga Inti & 23 & $65,7 \%$ \\
\hline Keluarga Besar & 4 & $11,4 \%$ \\
\hline KOS Sendiri & 5 & $14,3 \%$ \\
\hline Tinggal bersama Saudara & 3 & $8,6 \%$ \\
\hline TOTAL & $\mathbf{3 5}$ & $\mathbf{1 0 0}$ \\
\hline
\end{tabular}

Tabel 6 Distribusi frekuensi karakteristik responden berdasarkan kecemasan dalam merawat pasien covid-19

\begin{tabular}{|l|c|c|}
\hline \multicolumn{1}{|c|}{ Cemas } & Jumlah & $\begin{array}{c}\text { Presentase } \\
(\%)\end{array}$ \\
\hline Ya & 35 & $100 \%$ \\
\hline Tidak & 0 & $0 \%$ \\
\hline TOTAL & $\mathbf{3 5}$ & $\mathbf{1 0 0} \%$ \\
\hline
\end{tabular}

Berdasarkan tabel 6 didapatkan data dari 35 responden semuanya mengalami cemas $(100 \%)$

\section{DATA KHUSUS}

Tabel 7 Distribusi Frekuensi Dukungan Keluarga pada tenaga kesehatan (perawat) dalam merawat pasien penderita covid-19.

\begin{tabular}{|l|c|c|}
\hline $\begin{array}{c}\text { Dukungan } \\
\text { Keluarga }\end{array}$ & Jumlah & $\begin{array}{c}\text { Presentase } \\
(\%)\end{array}$ \\
\hline Baik & 15 & $42,8 \%$ \\
\hline Cukup & 18 & $51,4 \%$ \\
\hline Kurang & 2 & $5.7 \%$ \\
\hline TOTAL & $\mathbf{3 5}$ & $\mathbf{1 0 0} \%$ \\
\hline
\end{tabular}

Berdasarkan tabel 7 didapatkan data dari 35 responden sebagian besar memiliki dukungan keluarga kepada perawat yang merawat pasien Covid-19 sebagian besar pada tingkat cukup yaitu sebesar 18 responden $(51,4 \%)$.
Tabel 8 Distribusi Frekuensi Strategi Penanganan Kecemasan Responden dalam merawat pasien Penderita Covid-19

\begin{tabular}{|l|c|c|}
\hline $\begin{array}{c}\text { Strategi } \\
\text { Penanganan }\end{array}$ & Jumlah & $\begin{array}{c}\text { Presentas } \\
\text { e (\%) }\end{array}$ \\
\hline Baik & 23 & $65,7 \%$ \\
\hline Cukup & 12 & $34,3 \%$ \\
\hline Kurang & 0 & $0 \%$ \\
\hline TOTAL & $\mathbf{3 5}$ & $\mathbf{1 0 0 \%}$ \\
\hline
\end{tabular}

Berdasarkan tabel 8 didapatkan data dari 35 responden sebagian besar memiliki strategi penanganan kecemasan yang baik dalam mengatasi kecemasan merawat pasien Covid-19 yaitu sebanyak 23 perawat $(65,7 \%)$, strategi penanganan kecemasan yang cukup sebanyak 12 perawat $(34,3 \%)$ dan strategi penanganan kecemasan yang kurang tidak ada $(0 \%)$.

Tabel 9 Tabulasi Silang antara Tingkat Kecemasan dan Strategi Penanganan Kecemasan pada tenaga kesehatan (perawat) di surabaya dalam merawat pasien penderita covid-19.

\begin{tabular}{|c|l|l|l|c|c|}
\hline No. & $\begin{array}{l}\text { Dukungan } \\
\text { keluarga }\end{array}$ & \multicolumn{2}{|l|}{$\begin{array}{l}\text { Strategi Penanganan } \\
\text { Kecemasan }\end{array}$} & \multirow{2}{*}{ Jumlah } \\
\cline { 3 - 5 } & & Baik & Cukup & Kurang & \\
\hline 1. & Baik & $\begin{array}{l}14 \\
(40 \%)\end{array}$ & $\begin{array}{l}1 \\
(2,9 \%)\end{array}$ & $0(0 \%)$ & $\begin{array}{c}15 \\
(42,9 \%)\end{array}$ \\
\hline 2. & Cukup & $\begin{array}{l}8 \\
(22,8 \%)\end{array}$ & $\begin{array}{l}10 \\
(28,5 \%)\end{array}$ & $0(0 \%)$ & $\begin{array}{c}18 \\
(51,3 \%)\end{array}$ \\
\hline 3. & Kurang & $\begin{array}{l}1 \\
(2,9 \%)\end{array}$ & $\begin{array}{l}1 \\
(2,9 \%)\end{array}$ & $0(0 \%)$ & $\begin{array}{c}2 \\
(5,8 \%)\end{array}$ \\
\hline & Jumlah & $\begin{array}{l}23 \\
(65,7 \%)\end{array}$ & $\begin{array}{l}12(34,3 \\
\%)\end{array}$ & $0(0 \%)$ & $\begin{array}{c}35 \\
(100 \%)\end{array}$ \\
\hline & $\mathrm{P}=0,007$ & & & & \\
\hline
\end{tabular}

Berdasarkan tabel 8 di dapatkan data dari 35 responden, 14 responden (40\%) mendapat dukungan keluarga yang baik dan memiliki strategi penanganan kecemasan yang baik sedangkan responden yang mendapat dukungan keluarga yang cukup memiliki strategi penanganan kecemasan yang juga cukup sebanyak 10 Responden $(28,5 \%)$ dan yang mendapat dukungan 
keluarga cukup namun memiliki strategi penanganan kecemasan baik yaitu sebesar 8 responden $(22,8 \%)$. Dari hasil uji statistic Spearman didapat $\mathrm{p}=0,007$ yang artinya terdapat hubungan dukungan keluarga terhadap strategi penanganan kecemasan Perawat yang merawat pasien Covid-19.

\section{PEMBAHASAN}

\section{Dukungan Keluarga}

Berdasarkan data yang didapat dari 35 responden Sebagian besar mendapatkan dukungan cukup yaitu sebanyak 18 responden $(51,4 \%)$. COVID-19 sangat menular dan menyebar dengan cepat, petugas kesehatan garis depan menanggung beban kerja yang meningkat secara signifikan (Lilin Rosyanti, 2020). Perawat yang bekerja di ruang perawatan covid-19 mengalami kecemasan. Kecemasan yang mereka alami juga dialami oleh keluarga. Keluarga kuatir dan takut bila anggota keluarganya yaitu perawat akan tertular dan juga akan menularkan penyakit ini kepada mereka. Berdasarkan Tabel 2 tentang karakteristik tinggal serumah bersama dengan siapa, didapatkan hasil bahwa sebagian besar responden tinggal serumah dengan keluarga inti yaitu sebanyak 23 perawat $(65,7 \%)$ baik dengan status menikah atau belum menikah. Menurut Teguh (2020) inilah yang menjadi salah satu faktor mereka mengalami kecemasan karena pada saat merawat pasien positif Covid-19 ataupun melakukan pemeriksaan pada masyarakat yang memiliki gejala Covid-19. Para tenaga kesehatan khawatir bahwa mereka akan menularkan virus korona Covid-19 kepada keluarga. Selain perawat keluarga juga mengalami kecemasan sehingga dukungan yang diberikan kepada perawat dalam menangani kecemasan mereka dalam tingkat cukup.

Dukungan keluarga
penelitian ini dalam tingkat cukup
dikarenakan para perawat sudah
beradaptasi terhadap perubahan yang
terjadi atas pandemic covid-19 yang
sudah lebih dari 1 tahun ada di Indonesia
dan juga sudah terbiasa merawat pasien
penderita Covid-19. Menurut
Ramadhan, (2020) Satu hal yang dapat menyebabkan petugas kesehatan akan mengalami peningkatan kecemasan, salah satunya adalah kurangnya Alat Pelindung Diri (APD) di tempat kerjanya. Petugas kesehatan berisiko mengalami gangguan psikologis dalam merawat pasien Covid-19 karena perasaan depresi, penyebab utamanya adalah perlindungan diri yang masih kurang dari kebutuhan petugas Kesehatan (Lai et al., 2020). Dari data dilapangan juga ditemukan bahwa APD (Alat Perlindungan Diri) yang sediakan oleh Rumah Sakit cukup lengkap dan memadai untuk para perawat ditambah lagi para perawat juga sudah mendapatkan vaksin Covid-19 sehingga perawat semakin merasa aman dan dukungan keluarga yang diberikan juga dilihat sebagai sesuatu yang biasa sehingga didapatkan hasil dalam tingkat cukup.

\section{Strategi Penanganan Kecemasan}

Menurut data dari 35 responden mayoritas perawat memiliki strategi penanganan kecemasan yang baik yaitu sebanyak 23 perawat $(65,7 \%)$, strategi penanganan kecemasan yang cukup sebanyak 12 perawat $(34,3 \%)$ dan strategi penanganan kecemasan yang kurang tidak ada $(0 \%)$.

Menurut Rina Tri Handayani (2020), ada beberapa strategi yang dapat digunakan untuk mengatasi kecemasan yaitu menerapkan strategi koping yang mirip dengan perilaku gaya hidup positif yang dapat meningkatkan kesejahteraan kesehatan mental. Selanjutnya Rina menjelaskan bahwa perilaku gaya hidup 
positif yang dimaksud adalah makan makanan sehat, melakukan aktivitas fisik yang teratur, mempraktikkan kebersihan dan tidur yang baik, serta menjaga istirahat yang cukup antara sif. Strategi Penanganan Kecemasan dalam penelitian ini dalam tingkat baik dikarenakan perawat sudah terbiasa menjaga pola makan yang baik dan benar, rajin menjaga kebersihan diri, melakukan pola hidup sehat, menghindari perilaku berisiko tinggi dan mendapatkan dukungan yang cukup dari keluarga, selain itu para perawat juga telah mendapatkan vitmin rutin dari Rumah Sakit sebagai salah satu strategi agar para perawat memiliki imun yang baik saat merawat pasien Covid-19. Menurut Becker dalam Wawan dan Dewi (2011), perilaku kesehatan pada dasarnya adalah suatu respons seseorang terhadap stimulus yang berkaitan dengan sakit dan penyakit sehingga perilaku tersebut juga mempengaruhi seseorang untuk mengatasi kecemasan yang dialami. Perawat dinilai sudah mampu dan terbiasa melakukan strategi penanganan yang baik seperti menjaga pola makan yang baik dan benar, rajin menjaga kebersihan diri, melakukan pola hidup sehat dan menghindari perilaku berisiko tinggi dapat mengurangi tingkat kecemasan karerna hal ini merupakan bagian dari perilaku sehat yang dilakukan setiap hari sebagai tenaga Kesehatan.

Berdasarkan tabel 3 tentang karakteristik pendidikan didapatkan data bahwa sebagian besar responden memiliki pendidikan D3 Keperawatan. yaitu sebanyak 28 orang (80\%). Menurut Untari (2014) dijelaskan bahwa seorang dengan tingkat pendidikan yang rendah akan mudah mengalami kecemasan, hal ini dikarenakan semakin tinggi pendidikan akan mempengaruhi kemampuan berfikir seseorang. Pendidikan pada umumnya berguna dalam merubah pola pikir, pola bertingkah laku dan pola pengambilan keputusan. Tingkat pendidikan yang cukup akan lebih mudah dalam mengidentifikasi stresor dalam diri sendiri maupun dari luar dirinya. Tingkat pendidikan juga mempengaruhi kesadaran dan pemahaman terhadap stimulus. Dengan memiliki pendidikan D3 Keperawatan dinilai sudah mampu dalam meningkatkan pola pikir, pola tingkah laku dan pola pengambilan keputusan dalam menentukan strategi dalam menghadapi stressor yang ada pada masa pandemic ini, dan perawat juga dituntut untuk selalu bisa professional dalam memberikan perawatan kepada pasien dengan tidak membedakan kondisi apapun.

\section{Hubungan Dukungan Keluarga dan Strategi Penanganan Kecemasan Perawat dalam merawat pasien penderita covid-19}

Dari hasil uji statistik spearman antara Hubungan Dukungan Keluarga dengan Strategi Penanganan Kecemasan pada Perawat dalam merawat pasien penderita covid-19 menunjukan hasil signifikan dengan nilai $p=0,007$ atau nilai $p$ lebih kecil. Hasil ini menunjukkan bahwa terdapat hubungan antara dukungan keluarga dengan strategi penanganan kecemasan pada perawat dalam merawat pasien Covid-19.

Perawat yang memiliki dukungan keluarga yang baik juga menunjukkan bahwa dalam melakukan strategi penanganan kecemasan juga baik. Dukungan keluarga merupakan motivasi seseorang dalam segala hal apalagi dalam hal pekerjaan. Hal ini sesuai dengan penelitian Adhe (2019) Pengaruh Dukungan Sosial Keluarga Terhadap Kinerja Perawat RSUD Sulthan Daeng Radja Bulukumba bahwa Dukungan Sosial Keluarga berpengaruh positif dan signifikan terhadap Kinerja. Sesuai dengan hasil penelitian diatas menunjukkan bahwa perawat yang 
mendapat dukungan keluarga baik itu dukungan informasi, dukungan emosional, dukungan instrumental dan dukungan penghargaan mempunyai semangat dalam menjalankan tugasnya dan tetap dapat melakukan strategi mengatasi kecemasan dalam menjalankan tugas mereka merawat pasien covid-19.

Hasil penelitian ini juga didukung oleh penelitian yang dilakukan oleh Nuuferullah (2011) yang menyatakan bahwa bahwa dukungan sosial keluarga memiliki pengaruh terhadap burnout perawat, yang artinya semakin tinggi dukungan sosial yang di berikan maka semakin rendah tingkat burnout yang dialami perawat. Dalam penelitian ini perawat yang memiliki dukungan keluarga yang baik membuat perawat tersebut melihat keadaan lebih baik dan tidak merasa sendiri dalam menghadapi kondisi saat ini sehingga mampu melakukan strategi penanganan kecemasan dengan baik. Dukungan sosial keluarga dan adanya perhatian orang lain dapat membuat orang tahan terhadap tekanan (Andarika, Rita, 2004). Dalam penelitian ini menunjukkan bahwa dengan adanya dukungan keluarga yang baik maka perawat mampu bertahan dalam situasi yang menekan selama merawat pasien covid-19 sehingga dapat melakukan stategi penanganan kecemasan dengan baik juga.

\section{SIMPULAN DAN SARAN}

\section{Simpulan}

Dukungan keluarga kepada Perawat yang merawat pasien covid-19 sebagian besar dalam tingkat dukungan Cukup.

Strategi penanganan kecemasan yang sudah dilakukan perawat sebagian besar termasuk pada kategori baik.

Terdapat hubungan anatara dukungan keluarga dengan Strategi Penanganan
Kecemasan pada Perawat dalam Merawat Pasien Penderita Covid-19

\section{Saran}

Bagi Responden diharapkan dapat terus melakukan dan mempertahankan strategi penanganan kecemasan untuk mengurangi tingkat kecemasan yang dialami dalam merawat pasien penderita Covid-19

Bagi Keluarga diharapakan tetap mempertahan dan meningkatkan dukungannya kepada perawat yang merawat pasien covid-19.

Bagi Penelitian Selanjutnya mengenai faktor-faktor yang mempengaruhi strategi penanganan kecemasan bagi peneliti yang berminat untuk membuat penelitian lebih lanjut, mengenai factor-faktor yang mempengaruhi strategi penanganan kecemasan Perawat yang merawat pasien covid-19.

Bagi Tempat Penelitian diharapkan tetap mempertahankan kebutuhan APD dan dapat juga menghimbau para perawat untuk tetap menerapkan Strategi untuk mengatasi kecemasan ketika bekerja merawat pasien Covid-19.

\section{DAFTAR PUSTAKA}

Adhe Lely Serli Dewi (2019) engaruh Dukungan Sosial Keluarga Terhadap Kinerja Perawat RSUD Sulthan Daeng Radja Bulukumba Dengan Burnout Sebagai Variabel Intervening, Undergraduate (S1) thesis, Universitas Islam Negeri Alauddin Makassar. http://repositori.uinalauddin.ac.id/15359/

Andarika, Rita. 2004. "Burnout Pada Perawat Putri RS St. Elizabeth Semarang DitinjauDari Dukungan Sosial". Jurnal PSYCHE Vol.1 No.1. 
Annisa, D., \& Ifdil. 2016. Konsep Kecemasan (Anxiety) Pada Lanjut Usia (Lansia). Jurnal Konselor Universitas Padang, 5(2), 93-99. Diunduh dari ejournal.unp.ac.id/index.php/konselor/ article/download/6480/5041.

Balasubramanian, A. Paleri, Bennett, Paleri, (2020) „Impact of COVID-19 on the mental health of surgeons and coping strategies ${ }^{\text {ee }}$, Head and Neck, (May), pp. 1-7. doi: 10.1002/hed.26291.

Brooks, S K, Webster, RK, Smith, L E. Woodland, L, Wessely, S, Greenberg, N, and Rubin, GJ (2020) ,The psychological impact of quarantine and how to reduce it: rapid review of the evidence ${ }^{\text {ee }}$ The Lancet. doi: 10.1016/S0140-6736(20)30460-8.

Dinah, dkk (2020). Gambaran Tingkat Kecemasan Perawat Saat Pandemi Covid 19 Di Negara Berkembang Dan Negara Maju. Dinamika Kesehatan Jurnal Kebidanan dan Keperawatan Vol 11 No. 1

Fadli, dkk (2020). Faktor yang Mempengaruhi Kecemasan pada Tenaga Kesehatan Dalam Upaya Pencegahan Covid-19. Jurnal Pendidikan Keperawatan Indonesia. 8(1: 58-65)

Kementrian Kesehatan RI. 2020. Pedoman Dukungan Kesehatan Jiwa dan Psikosoial Pada Pandemi Covid-19. Jakarta : Direktorat Pencegahan dan Pengendalian Masalah Kesehatan Jiwa

Lai, J., Ma, S., Wang, Y., Cai, Z., Hu, J., Wei, N., Li, R. (2020). Factors Associated With Mental Health Outcomes Among Health Care Workers Exposed to Coronavirus Disease 2019. JAMA, 3(3), 1-12. https://doi.org/

10.1001/jamanetworkopen.2020.3976.

Irwanto. 2002. Psikologi Umum. Jakarta: PT. Prenhallindo.

Lilin Rosyanti, dkk (2020). Dampak Psikologis dalam Memberikan Perawatan dan Layanan Kesehatan Pasien COVID-19 pada Tenaga Profesional Kesehatan. https://myjurnal.poltekkeskdi.ac.id/index.php/HIJP

Nisya. (2013). "Prinsip-Prinsip Dasar Keperawatan" Cetakan 1. Jakarta: Dunia cerdas.

Nuuferulla Kurniantyas Pangastiti dan Mudji Rahardjo (2011) Analisis pengaruh dukungan social keluarga terhadap burnout pada perawat kesehatan di rumah sakit jiwa. http://eprints.undip.ac.id/29408/1/Jurn al_NUUFERULLA.pdf

Ramadhan, A. (2020). Vitalnya ketersediaan APD untuk melindungi tenaga kesehatan. Jakarta. Retrieved from https://www.antaranews.com/berita/14 11158/vitalnya-ketersediaanapduntuk-melindungi-tenagakesehatan

Ramsberger PF, Legree P, Milles L. Evaluation of the Buddy Team Assignment Program. Alexandria,

VA: United States Army Research Institute for the Behavioral and Social Sciences; 2003.

Rina Tri Handayani, dkk. (2020). Kondisi dan strategi penanganan kecemasan pada tenaga kesehatan saat pandemic covid-19. Jurnal Ilmu Keperawatan Jiwa. 3 (3:365 - 374) 
Siti Sundari. (2014). Kearah Memahami Kesehatan Mental. Yogyakarta : PPB FIP UNY.

Stuart \& Sundeen. 2000. Buku saku keperawatan jiwa. Jakarta: EGC

Taylor, Shelley E. 1999. Social Psychology. 10th Edition. Prentice Hall College Div.

Teguh Santoso, dkk (2020). Kondisi Psikologis Perawat yang Memberikan Asuhan Keperawatan pada Pasien COVID-19. Media Hospitalia Journal Of Clinical Medicine. 7 (1:253-260)

World Health Organization. 2020. Corona Virus Disease (COVID-19). Situation Report. 